International Section

Arch. Esp. Urol., 60, 3 (326-331), 2007

\title{
THE NATURAL HISTORY OF PEYRONIE'S DISEASE.
}

Marco Grasso, Caterina Lania', Salvatore Blanco and G. Limonta².

Department of Urology. Desio Hospital. Milan.

'Department of Urology. Institute San Raffaele. Milan.

${ }^{2}$ Department of Laboratory Medicine. University Milano-Bicocca. Hospital of Desio. Milan. Italy.

Summary.- OBJETIVE: Many physical or medical therapeutic approaches, systemic or local, have been suggested for treatment of Peyronie's disease. These approaches claim a discrete percentage of success in terms of clinical stabilization or improvement. The aim of our work was to evaluate the "natural history" of this disease.

METHOD: 110 patients affected by Peyronie's disease have been observed for at least five years. At the first visit all patients maintained sexual activity not requiring surgical approach. No medical or physical treatments have been performed on these patients. All patients un-
Marco Grasso

Via Mazzini, 1

20033 Desio. Milan. (Italy) marco.grasso@aovimercate.org

Acepted for publication: June $26^{\text {th }}, 2006$ derwent twelve months follow up for at least 5 years evaluating the natural progression of the disease by means of ultrasound and clinical examination. We made statistical analysis (Odds ratio, P for trend) to check if the$r e$ is association between clinical worsening requiring surgical treatment and: 7 - age of patients, 2-diabetes, 3- presence of close relative pattern for diabetes and 4-Dupuytren contracture.

RESULTS: Regarding curvature, number and size of fibrous plaques, a consistent tendency to stabilization has been observed in the group of patients above 50 years of age. $68 \%$ of the patients belonging to the group under 50 years showed a progressive worsening of the disease requiring surgical therapy, while in the other group only $31,5 \%$ of the patients required surgery. The statistical analysis confirmed that PD worsening is more probable in the group under 50 years of age $(O R=3.5, C l: 2-8)$ and in the patients affected by diabetes lage adjusted $O R=6, C l: 2-19)$. Statistical analysis has not shown significant differences in the evolution of Peyronie's disease regarding the presence of close relative pattern for diabetes and Dupuytren contracture.

CONCLUSION: The patients presented a discrete tendency to spontaneous stabilization. The patients who are diagnosed under the fiffies have a greater probability that the disease will worsen, requiring a surgical approach. The data regarding the natural history of Peyronie's disease in not treated patients should induce caution in awarding efficacy to new pharmacological and physical treatments.

Keywords: Peyronie's disease. Natural history. 
Resumen.- OBJETIVO: Para el tratamiento de la enfermedad de La Peyronie se han sugerido muchos abordajes terapéuticos físicos ymédicos, sistémicos y locales. Estos tratamientos suponen un discreto porcentaje de éxitos en términos de estabilización clínica o mejoría. El objetivo de nuestro trabajo es evaluar la historia natural de esta enfermedad.

MÉTODOS: 110 pacientes con enfermedad de La Peyronie fueron observados durante al menos cinco años. En la primera visita todos los pacientes mantenían actividad sexual y no tenían indicación para un abordaje quirúrgico. No se hizo tratamiento médico físico en estos pacientes. Todos los pacientes fueron seguidos de anualmente durante al menos cinco años, evaluando la progresión natural de la enfermedad por medio de ultrasonidos y exploración física. Realizamos un estudio estadístico (Odds ratio, P I para comprobar si existía asociación entre el empeoramiento clínico que requiriera cirugía y: 7-la edad del paciente; 2-diabetes; 3- un patrón de diabetes en la familia próxima; y 4-enfermedad de Dupuytren.

RESULTADOS: En relación con la curvatura y el número y tamaño de las placas fibrosas se ha observado una tendencia hacia la estabilización del grupo de pacientes de más de 50 años de edad. El 68\% de los pacientes del grupo de edad menor de 50 años mostraron un empeoramiento progresivo de la enfermedad requiriendo cirugía, mientras que en el otro grupo sólo el $37,5 \%$ de los pacientes necesitaron cirugía. El análisis estadístico confirmó que el empeoramiento de la enfermedad es más probable en el grupo menor de 50 años de edad $(O R=3,5, I C 2-8)$ y en los pacientes diabéticos (ajustando por edad $O R=6$, IC 2-19). El análisis estadístico no ha mostrado diferencias significativas en la evolución de la enfermedad de Peyronie en cuanto a la presencia de un patrón de diabetes en los familiares cercanos o de enfermedad de Dupuytren.

CONCLUSIONES: Los pacientes presentaron una discreta tendencia hacia la estabilización espontánea. Los pacientes diagnosticados antes de los 50 tiene una mayor probabilidad de empeoramiento de la enfermedad requiriendo un abordaje quirúrgico. Los datos sobre la historia natural de la enfermedad de Peyronie en pacientes no tratados deben transmitir cautela a la hora de considerar la eficacia de los nuevos tratamientos farmacológicos y físicos.

Palabras clave: Enfermedad de Peyronie. Historia natural.

\section{INTRODUCTION}

Peyronie's disease is a localized connective tissue disorder that primarily involves the tunica albuginea of the corpora cavernosa of the penis. Francois de La Peyronie (1678-1747) first described the condition in a treatise on ejaculatory failure (1). It usually presents with palpable induration of the penis (plaque). The formation of fibrotic plaques in the tunica albuginea and surrounding cavernosal tissue alters anatomy and cause acquired penile deformities during erection with different degrees of bending and narrowing. This condition presents with or without penile pain as well as erectile dysfunction.

At present the therapy is still controversial. General agreement does not exist neither about the utility of medical and physical treatment nor about the timing of surgical treatment. In the valuation of the results of the proposed treatments, the natural history of Peyronie's disease is not considered. The disease does not evolve in all patients, especially in the oldest ones (2). Natural history of the disease is still unclear, as the exact cause that remains unknown and has not been completely investigated despite the amount of time that passed since its first description (more than 250 years) and its relatively high prevalence (3). Without this information it is impossible to evaluate correctly the efficacy of various therapies suggested. To make clear natural history of Peyronie's disease it is also important to have data to compare in clinical treatment studies, in which there is not a no treatment arm. In our study we assessed natural history of Peyronie's disease based on at least 5 years period of clinical observation without administration of therapy.

\section{MATERIALS AND METHODS}

Between 1985 and 1999, 135 men affected by Peyronie's disease (PD) in an early phase not presenting erectile dysfunction underwent a detailed evaluation at our institution. 25 patients dropped-out: 10 for discontinuous follow-up, 15 because had developed erectile dysfunction not related to progression of $P D$, requiring for an immediate treatment with intracavernous injection of vasoactive agents. 97 patients were submitted at our attention by family doctors for penile disease, 38 by their own choice. For all the time of observation no medical or physical treatments concerning this disease were performed. We have decided not to consider for this study men affected by erectile dysfunction because these patients require an immediate good treatment. Patients have been observed for at least 5 years (mean 6.4 years). Patient's characteristics, such as age, co-morbidity, degree of 
curvature, size, number and position of plaque were determined. The degree of penis curvature was measured during maximum erection obtained after video sexual stimulation and manual genital self-stimulation.

Every twelve months a follow-up visit was performed with the use of ultrasound (examination done by a single ultrasonographer) for description of clinical evolution of plaques (number, size, location). We assessed the modification of sexual ability to intercourse, the presence of pain during erection and sexual intercourse, the change of penis deformation. Progression of the disease was defined as worsening of penis deformation or increased number of plaques not allowing normal sexual intercourse. We made statistical analysis (Odds ratio, $\mathrm{P}$ for trend) to check if there is association between clinical worsening requiring surgical treatment and: 1-age of patients, 2- diabetes, 3- presence of close relative pattern for diabetes and 4-Dupuytren contracture. The statistical analyses were performed with the use of SAS statistical software (version 8.2).

\section{RESULTS}

We evaluated 110 patients. Mean patients age was 53 (range 34 to 66). At the first visit all patients maintained sexual activity and surgical treatment wasn't required for severe penile deformities. The most commonly associated diseases were diabetes in $24.5 \%$ of cases, hypertension in $13.6 \%$, Dupuytren's contracture in $11 \%$ and ischemic cardiopathy in $3.6 \%$, the close relative pattern for diabetes in our group was $26 \%$ of non-diabetics patients (data regarding general population are not reported in literature) (Table I). None of the patients had previous histories of genital trauma. History of urethral infections was present in $10 \%$ of cases. According to the Kelami classification 43 (39\%) patients had mild (30 degrees or less) curvature or not curvature and $67(61 \%)$ had moderate curvature (between 31 and 60 degrees) (4). The most frequent penile abnormality was dorsal curvature in 28 cases $(25,5 \%)$. We divided patients into two groups. In the first one we considered patients under 50, in the second group we considered patients over 50 . At the inclusion visit, no patient had a plaque of extension higher than 2 $\mathrm{cm}$ or more than two plaques. We usually found it difficult to demonstrate by ultrasounds the presence of fibrosis of the septum detected through palpation; in the first group (patients under 50) there were 19pt with mild-curvatures, $15 \mathrm{pt}$ with curvatures associated with spontaneous pain or during intercourse and 13 with palpable plaque and pain. In the second group (patients over 50 ) there were $17 \mathrm{pt}$ with mild-curvatures, 26 pt with curvatures associated with pain and 20 with plaques and pain. During the 5 years of observation 22 patients over 50 and 18 patients under 50 had developed plaques above $2 \mathrm{~cm}, 19$ patients over 50 and 7 patients under 50 have had more than two locations (Table II). At the end of follow-up pain was referred as recurrent in 12 patients of the group under 50 and in 8 patients in the other group. 36 patients evolved into severe deformation not permitting intercourse. All 36 were submitted to prosthesis implant; in five patients we also made excisions of the plaques. Of this 36 patients 23 belonged to the group under 50 and only 13 to the group over 50 . Progressive worsening of deformation developed in $68 \%$ of patients in the group under 50 and $31.5 \%$ in the group over 50 (tab. III). Regarding curvature, number and size of fibrous plaques, a consistent tendency to stabilization has been observed in the group of patients over 50 years. The statistical analysis confirmed that PD worsening is more probable in the patients affected by diabetes (age adjusted $O R=6, C l: 2-19$ ) and in patients under 50 years of age $(O R=3.5, \mathrm{Cl}: 2$ 8).

TABLE I. THE MOST COMMONLY ASSOCIATED DISEASES.

\begin{tabular}{|l|l|l|l|l|}
\hline Prevalence of & $\begin{array}{l}\text { Dupuytren } \\
\text { Contracture }\end{array}$ & Diabetes & Ipertension & $\begin{array}{l}\text { Close relative pattern } \\
\text { for diabetes }\end{array}$ \\
\hline $\begin{array}{l}\text { Common } \\
\text { Population }\end{array}$ & $6 \%$ & $5 \%$ & $20 \%$ & $?$ \\
\hline $\begin{array}{l}\text { Patients } \\
\text { evaluated }\end{array}$ & $11 \%$ & $24.5 \%$ & $13.6 \%$ & $26 \%$ \\
\hline
\end{tabular}


Moreover a further division of patients in quartile of age had showed a significant statistical trend of reduction of evolution of the disease correlated with progression of the age $(\mathrm{P}$ value for trend $=$ $0.003)$, this is because of the considerable difference of the $1^{\text {st }}$ quartile (of reference) with the $4^{\text {th }}(p=0.008)$ and less with the $3^{\text {rd }}(p=0.05)$ (Table IV). Statistical analysis has not shown significant differences regarding the presence of close relative pattern for diabetes and Dupuytren contracture.

\section{DISCUSSION}

The most widely accepted theory claims that Peyronie's disease is induced by excessive fibrotic response of the tunica albuginea to prolonged micro trauma of erect penis. Trauma should be the initiating factor in people with personal predisposition to this disease as emerge from anatomical, pathological and clinical data $(5,6)$. Trauma or excessive bending of erected penis may be the cause of bleeding into the subtunical spaces and tunical delamination of the septum in the point in which integrates in the inner circular layer of the tunica albuginea. As initial consequence of trauma there is fibrin deposition. The presence of fibrin could be find in the plaques but it is absent in normal or scarred tunica albuginea (7). The basis of pathogenesis may involve fibrogenetic factors as TGF- $\beta 1$ or reactive oxygen species (ROS).
TGF- $\beta 1$ increases transcription and synthesis of collagen, proteoglycans and fibronectin in fibroblast and prevents connective tissue breakdown. TGF- $\beta 1$ could induce its own production and develop excessive scarring and fibrosis. TGF- $\beta 1$ is inducers of ROS formation and inhibitors of nitric oxide $(\mathrm{NO})$ synthesis resulting in a lowering of NO-to-ROS ratio causing abnormal wound healing $(8,9)$.

Different genes expression in tunica albuginea of normal patients and of patients affected by PD has been studied. In the tunica albuginea of patients affected by PD the genes responsible of collagen deposition, TGF- $\beta 1$ or collagen I, are up-regulated while genes opposing collagen accumulation are down regulated (10). To attest the genetic predisposition to the disease we add our personal experience concerning a series of 14 patients submitted to surgery for penile trauma occurred during sexual activity. After a follow-up of at least 3 years we observed the stabilization of the focal cicatricial fibrosis, in any case followed by fibrotic progression in the same location or in other point of the corpora cavernosa. In literature there are no data that report the appearance of PD in patients submitted to surgery for penile straightening with excision of a lozenge of tunica albuginea followed by suture. A comparison of the gene expression profiles between PD and Dupuytren's contracture suggest that they could have a common pathophysiology. In fact in both cases the same genes of collagen de-

TABLE II. CASE HISTORY.

\begin{tabular}{|l|}
\hline Case history at presentation \\
$\mathbf{4 7}$ patients $<50$ years \\
19 only with curvature \\
15 curvature + pain \\
131 or 2 plaques under $2 \mathrm{~cm}$ \\
63 patients $>50$ years \\
17 only with curvature \\
26 curvature + pain \\
20 one or 2 plaques under $2 \mathrm{~cm}$ \\
\hline
\end{tabular}

\section{Case history at the end of follow-up}

47 patients $<50$ years

7 more than 2 plaques

18 plaques above $2 \mathrm{~cm}$

63 patients $>50$ years

19 more than 2 plaques

22 plaques above $2 \mathrm{~cm}$ 


\section{TABLE III. NATURAL HISTORY OF PEYRONIE'S DISEASE.}

Natural history of P.D.

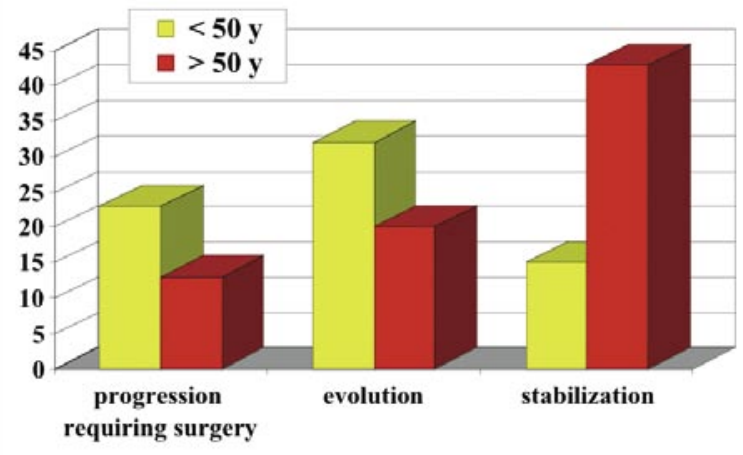

gradation (matrix metalloproteinase, thymosins), ossification (osteoblast specific factors) and myofibroblast differentiation are up-regolated (11).

The signs and symptoms of Peyronie's disease can be grouped into two phases: early inflammation (acute phase) and late fibrosis (chronic phase). Peyronie's disease is most commonly seen in the fifth decade of life. However, a wide range of on set age is reported (20-83y). The incidence of the disease is increasing in the last years.
The true prevalence is unknown and may be higher than previously reported considering the reluctance of the patient to report to the physicians this embarrassing condition. Sommer et al reported a prevalence rate of $3.2 \%$ in male inhabitants of the Cologne-Germany area (12). In literature there are not guidelines for the therapeutical management of PD. Many therapies have been suggested. Actually a patient has three treatments options: drugs, physical therapy and surgery. Many drugs, are administered systemically or intralesionally with the use of devices. The oral therapy has been suggested in several studies with different in-take modality drugs as colchicina, tamoxifen, acetyl l-carnitine, vitamin $\mathrm{E}$, dexamethasone, stigmasterolo, allopurinolo, dipiridamolo and POTABA (potassium aminobenzoate) (13). Local administration of thiomucase, collagenase, corticosteroid, orgotein, parathormone, dexamethasone, verapamil and interferon- $\alpha$ has been tested $(14,15)$. Numerous physical devices have been tested on plaques: infrared rays, ultraviolet rays, microwave, ultrasounds, laser, ESWL and X-rays (16). Surgical procedure is reserved to a minority of patients with a high degree of curvature or narrowing that does not permit sexual intercourse or to patients with associated severe erectile dysfunction. Three groups of techniques are been suggested: tunical shortening procedures (straightening corporoplasty) such Nesbit's or Yachia's procedure $(17,18)$, tunical lengthening procedures as incision or excision of fibrous plaque with implantation of autologous or heterologous patch to cover the defect using dermis,

TABLE IV. STATISTICAL ANALYSIS.

\begin{tabular}{|c|c|c|c|c|c|}
\hline & \multicolumn{4}{|c|}{ Age quartiles } & \multirow{2}{*}{$\begin{array}{l}\text { P value } \\
\text { for trenc }\end{array}$} \\
\hline & $\begin{array}{l}1 s t \\
34-44 \text { years }\end{array}$ & $\begin{array}{l}\text { 2nd } \\
45-52 \text { years }\end{array}$ & $\begin{array}{l}3 \mathrm{rd} \\
53-61 \text { years }\end{array}$ & $\begin{array}{l}\text { 4th } \\
61-66 \text { years }\end{array}$ & \\
\hline Patients evolved & 14 & 11 & 7 & 4 & \\
\hline Patients included & 28 & 27 & 28 & 27 & \\
\hline Odds (95\% Cl) & 1.0 (referent) & $0.7(0.2-2.0)$ & $0.3(0.1-1.0)$ & $0.2(0.05-0.6)$ & 0.003 \\
\hline$P$ value & & 0.49 & 0.05 & 0.008 & \\
\hline
\end{tabular}


dura mater, funica vaginalis, saphenous vein, pericardial graft, Gore-Tex ${ }^{\circledR}, \operatorname{Dacron}^{\circledR}(19)$, and prosthesis (inflatable or semirigid) implantation20. The timing of surgical treatment is still discussed. All the developed therapies have not resulted in a reliable and definitive treatment. In literature papers with randomised series and sufficient follow-up are not available. The certain possibility to reduce the worsening of the disease has not yet been demonstrated. In the western countries at our knowledge no drugs has been authorized, by specific governments organs (ex: health minister), for the treatment of PD. This is mainly due to the lack of knowledge about an accurate model of evolution of the disease.

\section{CONCLUSION}

Our study had showed the frequent absence of clinical progression of this disease for many years and the different evolution of sign and symptoms related to the age of the patient. Our findings highlight not only the known comorbidity of diabetes in these patients, but also the high close relative pattern of diabetes. This fact suggests that diabetes could not be a cause of the disease but in diabetics patients there could be a genetics predisposition to Peyronie's disease.

Considering the frequent stabilization of the disease, often not requiring any therapeutical approach, great attention should be put in the evaluation of the efficacy of pharmacological and physical treatments.

\section{REFERENCES AND RECOMENDED READINGS (*of special interest, ${ }^{* *}$ of outstanding interest)}

*1. DUNSMUIR, W.D.; KIRBY, R.S.: "Francois de LaPeyronies (1678-1747): the man and the disease he described". BJU, 78: 613, 1996.

*2. WILLIAMS, J.L.; THOMAS, G.G.: "The natural history of peyronie's disease". J. Urol., 103: 75, 1970.

*3. SCHWARZER, U.; SOMMER, F.; KLOTZ, T. y cols.: "The prevalence of Peyronie's disease: results of a large survey". BJU Int., 88: 727, 2001.

4. KELAMI, A.: "Classification of congenital and acquired penile deviation". Urol. Int., 38: 229, 1983.
**5. DEVINE, C.J.Jr;; SOMERS, K.D.; JORDAN, G.H. y cols.: "Proposal: trauma as the cause of the Peyronie's lesion”. J. Urol., 157: 285, 1997.

6. JAROW, J.P.; LOWE, F.C.: "Penile trauma: an etiologic factor in Peyronie's disease and erectile dysfunction". J. Urol., 158: 1388, 1997.

**7. SOMERS, K.D.; DAWSON, D.M.: "Fibrin deposition in Peyronie's disease plaque". J. Urol., 157: 311, 1997.

**8. BORDER, W.A.; RUOSLAHTI, E.: "Transforming growth factor-beta in disease: the dark side of tissue repair". J. Clin. Invest., 90: 1, 1992.

*9. FERRINI, M.G.; VERNET, D.; MAGEE, T.R. y cols.: "Antifibrotic role of inducible nitric oxide synthase". Nitric Oxide, 6: 283, 2002.

*10. MAGEE, T.R.; QIAN, A.; RAJFER, J. y cols.: "Gene expression profiles in the Peyronie's disease plaque". Urology, 59: 451,2002.

11. QIAN, A.; MEALS, R.A.; RAJFER, J. y cols.: "Comparison of gene expression profiles between Peyronie's disease and Dupuytren's contracture". Urology, 64: 399, 2004.

12. SOMMER, F.; SCHWARZER, U.; WASSMER, G.: "Epidemiology of Peyronie's disease". Int. J. Impot. Res., 14: 379, 2002.

13. HASCHE-KLUNDER, R.: "Treatment of peyronie's disease with para-aminobenzoacidic potassium (POTOBA)". Urologe A, 17: 224, 1978.

14. DANG, G.; MATERN, R.; BIVALACQUA, T.J. y cols.: "Intralesional interferon-alpha-2B injections for the treatment of Peyronie's disease". South Med. J., 97: 42, 2004.

15. LEVINE, L.A.; GOLDMAN, K.E.; GREENFIELD, J.M.: "Experience with intraplaque injection of verapamil for Peyronie's disease". J. Urol., 168: 621, 2002.

16. HAUCK, E.W.; MUELLER, U.O.; BSCHLEIPFER, T. y cols.: "Extracorporeal shock wave therapy for Peyronie's disease: exploratory metaanalysis of clinical trials". J. Urol., 171: 740, 2004.

17. NESBIT, R.M.: "Congenital curvature of the phallus: report of three cases with description of corrective operation". J. Urol., 93: 230, 1965.

18. YACHIA, D.: "Modified corporoplasty for the treatment of penile curvature". J. Urol., 143: 80, 1990.

19. LUE, T.F.; EL-SAKKA, A.I.: "Venous patch graft for Peyronie's disease. Part I: technique". J. Urol., 160: 2047, 1998.

20. MULCAHY, J.J.; WILSON, S.K.: "Management of Peyronie's Disease with penile prostheses". Int. J. Impot. Res., 14: 384, 2002. 